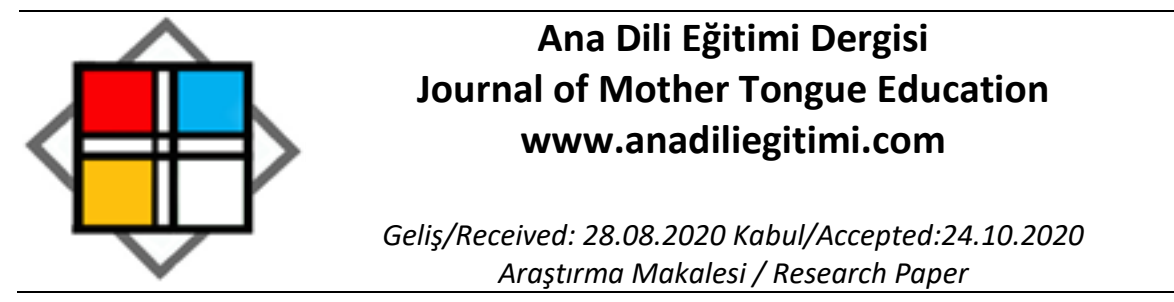

\title{
İşitme Engelliler İlkokullarında Kullanılan Türkçe Kitaplarındaki Etkinliklerin Görsel Okuryazarlık Becerileri Açısından İncelenmesi
}

\author{
Süleyman DOĞRU* \\ Simge CEPDIBi* \\ S. Sunay YILDIRIM DOĞRU***
}

\begin{abstract}
Özet
Bilimsel dayanaklarla doğruluğu kanıtlanmamış olmakla beraber, işitme yetersizliği olan bireylerin bir kısmının görsel bir dil olan işaret dili kullanmasına veya işitsel bilgiye nazaran görsel bilgiyi tercih etmesinden dolayı onların görsel öğreniciler oldukları düşünülür. Çağımızda ise, görsel okuryazarlık becerileri her eğitim kademesindeki birey için önemli bir beceri alanıdır. Bu sebeple, bu araştırmanın amacı 2018 Türkçe öğretim programındaki (1. sınıflar) görsel okuryazarlık beceri alanına ait olduğu düşünülen kazanımlarının belirlenmesi ve belirlenen kazanımlarla ilişkili etkinliklerin işitme engelliler ilkokullarında kullanılan Türkçe ders kitaplarında yer alma durumunun incelenmesi olarak belirlenmiştir. Çalışmanın verileri doküman incelemesi yoluyla elde edilmiş, kategorik kodlama matrisi kullanılarak analiz edilmiştir. Illkokul Türkçe 1 kitabında görsel okuryazarlık becerileriyle ilişkili 43 etkinlik, işitme engelli öğrenciler için hazırlanan Türkçe yardımcı ders kitabında ise 106 etkinlik tespit edilmiştir. Çalışmada işitme yetersizliği olan öğrenciler için hazırlanan yardımcı ders kitabının görsel okuryazarlık beceriyle ilişkili etkinlikler açısından zengin olduğu tespit edilmiştir. Fakat işitme engelli öğrenciler için hazırlanan Türkçe 1 yardımcı ders kitabında dinleme boyutuna ait kazanımlara ilişkin etkinliklerin bulunmadığı araştırma sonunda önemli bir eksiklik olarak tespit edilmiştir. Çalışma sonunda Türkçe ders ve etkinlik kitaplarında dil ve dile ait tüm boyutlarının bütüncül bir şekilde ele alınması ve görsel okuryazarlık becerilerinin dile ait tüm boyutlarda desteklenmesi yönünde öneriler geliştirilmiştir.
\end{abstract}

Anahtar Kelimeler: Görsel okuryazarlık, işitme yetersizliği olan çocuklar, Türkçe öğretim programı

\section{Investigation of the Activities in Turkish Textbooks Used in Primary Schools for Deaf in Terms of Visual Literacy Skills}

\begin{abstract}
Although the validity of this idea has not been evidenced with scientific research, it is thought that deaf people have a visual learning style because of the use sign language, which is a visual language, or more prefer to visual information than auditory information. In our age, visual literacy skills are an important skill for individuals of all education levels. Therefore, the aim of the study to determine objectives relevant to visual literacy in 2018 Turkish curriculum (only 1st grade) and, examine activities relevant to determined objectives in Turkish textbook which used in primary schools for deaf. The data of the research was acquired by way of document review and in analyzing process a categorical encoding matrix was used. 43 activities relevant to visual literacy in the Turkish 1 textbook and 106 activities in the Turkish 1 elementary supplementary textbook for
\end{abstract}

\footnotetext{
* Dr. Öğr. Üyesi, Biruni Üniversitesi, Eğitim Fakültesi, Özel Eğitim, İstanbul, dogruib@gmail.com, ORCID: 00000002-1942-4781

** Arş. Gör., İstanbul Üniversitesi-Cerrahpaşa, Hasan Ali Yücel Eğitim Fakültesi, Özel Eğitim, İstanbul, simge.cepdibi@istanbul.edu.tr, ORCID: 0000-0002-7783-7058

${ }^{* * *}$ Prof. Dr., Dokuz Eylül Üniversitesi, Buca Eğitim Fakültesi, Özel Eğitim, İzmir, sunay.dogru@deu.edu.tr, ORCID: 0000-0003-0573-0128
} 
the deaf were determined. In the research, the Turkish 1 elementary supplementary textbook for the deaf was determined to be rich in activities related to visual literacy. However, the lack of visual literacy activity in the listening dimension in the Turkish 1 elementary supplementary textbook was identified as important deficiency at the end of the research. At the end of the research, suggestions were developed to support all language and language dimensions holistically in Turkish textbooks and activity books and, visual literacy skills in all dimensions of language.

Keywords: Visual literacy, children with hearing impairment, Turkish curriculum

\section{Giriş}

Eğitim sistemimizde ilkokul düzeyi bireyin gelişiminde önemli bir rol oynamaktadır. Çünkü bireyin gelecekteki akademik ve gündelik yaşamı açısından ilk okuma yazma öğretimi kritik bir role sahiptir. Günümüz dünyasındaki okuryazarlık ise giderek artan bir görsellik kazanmaktadır. Bu sebeple, ilk okuma yazma öğretimi programlarında görsel okuryazarlığa gerekli önemin verilmesi öğrencilerin içinde bulunduğu çağı yakalamasını kolaylaştıracaktır. Kısaca artık çağımızda görsel imgelerle kuşatımış bir hayata uyum sağlayabilmek için sadece geleneksel anlamda metne dayalı okuryazar olmak yeterli olmamaktadır (Barner, 1997). Görsel okuryazarlık giderek artan önemiyle genel eğitimde kazandırılması gereken temel beceriler arasında yer almaktadır (Akpınar, 2009). "Görsel okuryazarlık becerileri" 2018 Türkçe Öğretim Programında da (MEB, 2018) kendine yer bulmuş ve program "görsel okuryazarlık becerileri" gelişimine hizmet eden kazanımlara yer vermiştir. Yer alan bu kazanımlar görsel mesajları anlamlandırma ve benzeri biçimde mesaj oluşturmaya hizmet etmektedir (Alpan Bangir, 2008). Görsel okuryazarlık becerileri özellikle eğitimciler için öğretme öğrenme sürecinin niteliğinin artırımasında kullanılabilecek önemli bir yetidir. Ayrıca farklı gereksinimleri olan ve farklı şekilde sunulmuş bilgiye ihtiyacı olan öğrenciler için de görsel okuryazarlık becerilerinin kazandırılması ve desteklenmesi önem arz etmektedir.

Bireyselleştirilmiş bir eğitim gerektiren grup içinde yer alan işitme yetersizliği olan öğrencilerin akademik yaşamları boyunca görsel öğrenme stillerine sahip olduğu düşünülür (Marschark ve ark., 2016). Bu görüş daha çok işitme yetersizliği olan öğrencilerin kullandığı işaret dilinin görsel bir dil olmasına ve işitme yetersizliği olan öğrencilerin işitsel bilgi yerine genellikle görsel bilgiyi tercih etmelerine dayanır. Buna rağmen bu kanı henüz bilimsel araştırmalarla desteklenmemiştir. Grafik, tablolar ve diyagramların kullanımının ise her gelişim düzeyinden öğrencinin yeni bilgiyi edinme sürecinde kolaylaştırıcı etkisinin olduğu bilinmektedir. Ayrıca grafiklerin, sembollerin okuma yazma öğretimine yönelik sıkça kullanıldığı ve özel eğitime ihtiyaç duyan bireylerin grafik sembolleri yazılı kelimelerden daha büyük bir kolaylıkla tanımlama eğilimleri olduğunun da altı çizilmektedir (Karal, Şılbır, Bahçekapılı \& Atasoy, 2015). Fakat öğrencilerin grafik ve sembolleri okuyabilmesi için gerekli olan becerilerin öğrencilere ders kitapları ve içindeki etkinliklerle kazandııılıyor olması beklenmektedir.

Örs ve Baş (2017), Türkçe 1-5. sınıflar programında yer alan 2. sınıfa ait görsel okuma ve görsel sunu kazanımlarıyla ilişkili etkinlikler oluşturmuşlar ve hazırlanan etkinliklerin görsel okuryazarlık gelişimine etkisini eylem araştırması yaparak incelemişlerdir. Çalışma sonunda ise, ilgili kazanımları geliştirmede etkinliklerin çalışma grubu için ilerletici olduğu sonucuna ulaşılımıştır. Temizkan ve Ünlüoğlu (2017), görsel materyallerle destekledikleri yazma çalışmasının öğrencilerin yazma başarısı ve yazmayla ilgili görüşleri üzerinde etkisini incelemişlerdir. Çalışma sonunda, görsel materyallerle destekli yazma etkinliklerinin öğrencilerin yazma başarılarını arttırdığı tespit edilmiştir.

Görüldüğü üzere hedef kazanımlar eğitim ortamlarında öğrencilere çeşitli yollarla kazandırılmaya çalışılmaktadır. Fakat, eğitim ortamlarında ki eğitsel hedeflere ulaşmak için uygun araç ve gereçlerin, uygun yer ve zaman da kullanılması çok önemlidir (Demirel \& Kıroğlu, 2019). Bu sebepledir ki ders kitapları, planlı ve programlı eğitim çalışmalarında kullanılan en temel materyalden biridir. Milli Eğitim Bakanlığı, Ders Kitapları Yönetmeliğinde ders kitabını, "her tür ve derecedeki örgün ve yaygın eğitim kurumlarında kullanılacak olan, konuları öğretim programları doğrultusunda hazırlanmış, öğrenim amacı ile kullanılan basılı eser" olarak ele almaktadır (Milli Eğitim Bakanlığı Ders Kitapları ve Eğitim Araçları Yönetmeliği, 2012). Illgili alan yazın sınıfta en önemli aracın ders kitabı olduğu ve öğretmenlerin de sıklıkla kullandığı materyalin ders kitapları olduğunu göstermektedir 
(Ceyhan \& Yiğit, 2005). Fakat TÜBA 2005'te yayımladığı raporda ders kitaplarını içerik açıdan yetersiz olarak tanımlamıştır (Akt: Demirel \& Kıroğlu, 2019)

Oysaki eğitimde temel materyal olan ders kitapları özellikle etkili öğrenme yaşantıları için çok önemlidir. Etkili öğrenme yaşantılarının ise bireylerin çeşitli duyu organlarına hitap etmesi ile gerçekleşebileceği bilindiğinden ders kitaplarının bu sürece ayak uydurabilmesi gerekmektedir (EARGED, 2008). Ayrıca, iyi bir ders kitabının eğitim programıyla da tam tutarlı olması beklenmektedir. Ders kitabını ele alırken ise içerik kadar içeriğe ilişkin etkinlikler de önem arz etmektedir. Bu sebeple ders kitaplarında yer alan etkinliklerin iyi hazırlanmış olması gerekmektedir. Çünkü eğer etkinlikler programın amacından uzaklaşmışsa veya tasarlanan etkinlikler öğrenme süreçlerine dahil edilmediyse öğrenme için amaçlanan kalıcılık ve anlamlılık seviyesine öğrenciler tarafından ulaşılmayabilmektedir (Özmantar \& Bingölbali, 2009). Gerekli öğrenme yaşantılarını sağlamak ve eğitim programlarının hedef davranış örüntülerini öğrenciye kazandırabilmek amacıyla ders kitaplarının mümkün olduğunca çok ve çeşitli etkinliklerle donanmış olması gerekmektedir.

Eğitim sürecinde öğrenme etkinlikleri ödev, alıştırma, etkinlik, performans ödevi gibi etkinliklerle çeşitli türlerde gerçekleştirilebilmektedir. Bunlardan en yaygın olanı ise; alıştırma ve etkinlik kullanımıdır (Çevik \& Güneş, 2017). Özellikle iyi planlanmış alıştırma ve etkinlikler çocuklarda etkili öğrenmenin gerçekleştirilmesi açısından çok önemlidir (Özden, 2005).

İ̧itme yetersizliği olan çocuklar ise, eğitim süreçlerinde normal gelişen akranlarına kıyasla bilginin daha çok tekrarlanmasına, ilgi çekici okuma materyallerinin kullanılmasına ihtiyaç duyarlar (Luckner, Sebald, Cooney, Young III \& Muir, 2005/2006). Bu sebeple işiten akranlarına kıyasla daha çok öğrenme etkinliklerinin içinde bulunmalarının onların öğrenme süreçlerini destekleyeceği düşünülmektedir. Yapılan araştırmalar, okuduğunu anlamada işiten akranlarına kıyasla daha geride olan işitme yetersizliği olan öğrencilere okuyacakları öyküleyici metinlerle birlikte sunulan videolar, görseller ve kavram haritalarının onların görsel kaynakların anlamına ulaşmada ve ulaştıkları bu anlamları okuduğunu anlamada kullanabilmelerine yardımcı olduğunu göstermektedir (Girgin, 1997; Nikolaraizi, Vekiri \& Easterbrooks, 2013). İşitme yetersizliği olan bireyler kullandıkları işaret dilinden dolayı çoğu zaman karmaşık görsel dil pratiklerinde bulunmaktadır. Görsel dilde var olan becerilerini, görsel okuryazarlık alanında kullanmak ve geliştirmek işitme yetersizliği olan öğrencileri yeni bir okuryazarlık türü olan görsel okuryazarlıkta yetkin kılacak ve gelişen toplumla bütünleşmesini kolaylaştıracaktır. Görselleri anlamayı ve görsellerle kendini ifade etmeyi öğrenen işitme yetersizliği olan bireyler için görsel okuryazarlık onların kendi potansiyellerini ortaya koyabilecek bir beceri alanı olarak düşünülmektedir. Bu beceri alanının sistematik bir şekilde öğretilmesi bu sebeple önem taşımaktadır.

Bu beceri alanıyla ilgili yapılan çalışmalara baktığımızda, Özaydınlı Tanrıverdi ve Apak Tezcan (2013), görsel okuryazarlıkla ilgili son on yılda yapılan çalışmaları incelediği araştırmasında, yapılan 29 çalışmanın normal gelişim gösteren öğrencilerle yapıldığını sadece 6 çalışmanın özel gereksinimli bireylerde görsel okuryazarlık becerisinin araştırıldı̆ını ortaya çıkarmıştır. Bununla birlikte, özel gereksinimli bireylerle yapılan bu 6 çalışmanın 5'i zihin yetersizliği olan öğrencilerle, 1 'i ise görme yetersizliği olan öğrencilerle yapılmıştır. Fakat görsel bir dil olan işaret dilini kullanılan işitme yetersizliği olan öğrencilerde görsel okuryazarlık becerilerinin araştırıldığı bir çalışmaya ulusal alan yazında rastlanmamıştır.

$\mathrm{Bu}$ nedenle bu çalışmada işitme yetersizliği olan öğrencilerle kullanılan "İ̧̧itme Engelli Öğrenciler için Hazırlanan Yardımcı Türkçe 1 Ders Kitabının" görsel okuryazarlık becerilerini destekleme açısından ne durumda olduğu belirlenmeye çalışılacaktır. Hem normal işiten hem de işitme yetersizliği olan çocukların kullandığı Türkçe İlkokul 1. sınıf ders kitabı da görsel okuryazarlık becerilerini destekleme açısından incelenecektir. Bu kitabında çalışmaya dahil edilmesinde amaç işitme yetersizliği olan ve işitme engelliler ilkokuluna devam eden öğrencilerin her iki kitabı da ders kitabı olarak kullanmasıdır. İncelenecek öğrenme alanının "görsel okuryazarlık" olarak seçilmesinde ise işitme yetersizliği olan çocukların güçlü yanlarının desteklenmesi düşüncesi rol oynamıştır. Bu çalışmanın alt problemlerini ise; a) Çalışmada incelenen İlkokul Türkçe 1 ve İşitme Engelli Öğrenciler için Hazırlanan Yardımcı Türkçe 1 Ders kitaplarında bulunan görsel okuryazarlık gelişimine yönelik etkinliklerin tema başına yer alma durumu, b) Çalışmada incelenen Illkokul Türkçe 1 ve İşitme Engelli Öğrenciler için 
Hazırlanan Yardımcı Türkçe 1 Ders kitaplarında yer alan görsel okuryazarlık gelişimine yönelik etkinliklerin dil beceri alanlarına göre yer alma durumu ve c) Çalışmada kullanılan illkokul Türkçe 1 ve İşitme Engelli Öğrenciler için Hazırlanan Yardımcı Türkçe 1 Ders kitaplarında yer alan görsel okuryazarlık gelişimine yönelik etkinliklerin Türkçe Illkokul 1. sınıf Ders Programında yer alan görsel okuryazarlıkla ilişkili kazanımlara göre yer alma durumu oluşturmaktadır.

\section{Araştırmanın Modeli}

\section{Yöntem}

Bu araştırmanın amacı "ilkokul Türkçe 1 ders kitabı (Civelek, Gündüz \& Karafilik, 2019)" ve "illkokul Türkçe 1 işitme engelli öğrenciler için hazırlanan yardımcı ders kitabında (Artam \& Baştuğ, 2017)" yer alan etkinlikleri "1. Sınıf Türkçe Dersi Öğretim Programındaki(MEB, 2018)" görsel okuryazarlık becerilerinin gelişimine hizmet ettiği düşünülen kazanımları içerip içermemesi yönünden değerlendirmektir. Bu sebeple bu araştırmada nitel araştırma desenlerinden olan doküman incelemesi yöntemi kullanılmıştır. Araştırmanın nesnesi "illkokul Türkçe 1 ders kitabı (Civelek, Gündüz \& Karafilik, 2019)" ve " illkokul Türkçe 1 işitme engelli öğrenciler için hazırlanan yardımcı ders kitabı(Artam \& Baştuğ, 2017)" olarak belirlenmiştir. Yapılan incelemeyle kitapların "1. Sınıf Türkçe Dersi Öğretim Programında (MEB, 2018)" yer alan ve görsel okuryazarlık gelişimine hizmet ettiği düşünülen kazanımları içerme durumu ve yeterlilik gibi nitelikleri belirlenmeye çalışılış̧ır.

\section{Verilerin Toplanması}

Çalışmanın verileri doküman incelemesi yoluyla elde edilmiştir. Doküman incelemesi, yazıı malzemenin toplanıp incelenmesi olarak tanımlanabilmektedir (Sönmez ve Alacapınar, 2018). ilk olarak 1. Sınıf Türkçe Dersi Öğretim Programında yer alan kazanımlar incelenmiş ve görsel okuryazarlık becerileri gelişimine destek verdiği düşünülen kazanımlar belirlenmiştir. Belirlenen kazanımlar alanında uzman iki öğretim üyesi tarafından görsel okuryazarlıkla ilgili olup olmama özelliğine göre değerlendirilmiştir. Değerlendirmenin sonunda görsel okuryazarlıkla ilgili olduğu düşünülen 7 kazanım belirlenmiştir. Bu kazanımlar, dinleme boyutuna ait; " Görsellerden hareketle dinleyeceği/izleyeceği metin hakkında tahminlerde bulunur." kazanımı, anlama boyutuna ait; "Görsellerle ilgili soruları cevaplar.", "Görsellerden hareketle okuyacağı metnin içeriğini tahmin eder." ve "Şekil, sembol ve işaretlerin anlamını kavrar." kazanımları, okuma boyutuna ait; "Görsellerden hareketle kelimeleri ve anlamlarını tahmin eder." kazanımı ve son olarak yazma boyutuna ait olan " Görsellerle ilgili kelime ve cümleler yazar." ve "Yazılarını görsel unsurlarla destekler." kazanımlarıdır.

Araştırmada, "illkokul Türkçe 1 ders kitabı (Civelek, Gündüz \& Karafilik, 2019)" ve " illkokul Türkçe 1 işitme engelli öğrenciler için hazırlanan yardımcı ders kitabında(Artam \& Baştuğ, 2017) yer alan tüm etkinlikler incelenmiştir. Bu kitaplar "ölçüt örneklem" yöntemine göre, devlet kitapları olarak geçen ve devlet okullarında okutulan kitaplar olması göz önünde bulundurularak amaçlı olarak seçilmiştir. Görsel okuryazarlık becerilerini geliştirmeye daha ilk okuma yazma döneminde başlamak önemlidir. Bu nedenle 1. sınıf Türkçe ders kitaplarında yer alan etkinliklerin görsel okuryazarlık becerilerine hizmet etme durumu araştırılmıştır. Araştırmada işitme engelliler ilkokullarında kullanılan Türkçe 1 Ders kitabı ile işitme yetersizliği olan öğrenciler için hazırlanmış yardımcı Türkçe Ders Kitabı olmak üzere toplamda iki kitap çalışma materyali olarak seçilmiştir. 2 kitap kapsamında toplam 355 etkinlik değerlendirilmiştir. 1. Sınıf Türkçe Öğretim Programında yer alan kazanımlar görsel okuryazarlık becerileriyle ilişkili olma durumuna göre incelenip 4 temel dil becerisi boyutunda gruplandırılmıştır.

\section{Verilerin Analizi}

Verilerin analizine başlamadan önce, 1 . Sınıf Türkçe Öğretim Programında yer alan tüm kazanımlar detaylıca incelenmiş ardından ise ders kitaplarında yer alan tüm etkinlikler kazanımlar doğrultusunda detaylıca taranmıştır. Maxwell'in (2013), benzerlik ilişkilerine dayanan analitik strateji olarak tanımladığı sınıflandırma stratejisi bu çalışmada kullanılıı̧tır. Öğretim programında görsel okuryazarlıkla ilişkili olduğu düşünülen 7 kazanıma göre kategoriler oluşturulmuştur. Belirlenen kategoriler sonrasında her etkinliğe notlar düşülmüş ve belirlenen görsel okuryazarlık kazanımlarıyla ilişkisi hakkında fikirler not edilmiştir. Öğretim programında görsel okuryazarlıkla ilişkili olduğu 
düşünülen 7 kazanıma göre kategorileştirilen görsel okuryazarlık becerilerini etkinliklerin içerme durumu ise bu kategoriler aracılığıyla yapılmış ve etkinlikler gruplandırımıştır. Gruplandırma işleminde ise, kategorik kodlama matrisi kullanılış̧ır. Araştırmacıların her biri ilk olarak bireysel, sonrasında toplu olarak değerlendirmeler yapmış ve kodlama işlemi tamamlanmıştır. Kodlama işlemi sonunda elde edilen veriler yüzde ve frekans analizi yapılarak tablolaştırılmıştır.

\section{Bulgular}

Araştırmada, ilkokul 1 Türkçe ders kitabı ve işitme yetersizliği olan öğrenciler için hazırlanan ilkokul Türkçe 1 yardımcı ders kitabı içerdikleri etkinlik ve hazırlık soruları açısından 1. sınıf Türkçe Öğretim Programında yer alan ve görsel okuryazarlık kazanımlarıyla ilişkili olduğu düşünülen araştırmacılar tarafından belirlenmiş 7 kazanıma yer vermesi bağlamında incelenmesi sonucu aşağıdaki bulgulara ulaşılmış ve elde edilen bulguların yorumlaması yapılmıştır.

Tablo 1.

Tema Başına Düşen Etkinliklerin Yoğunluk Durumu

\begin{tabular}{lcccc}
\hline Kitap & $\begin{array}{c}\text { Tema } \\
\text { Sayısı }\end{array}$ & $\begin{array}{c}\text { Toplam } \\
\text { Etkinlik }\end{array}$ & $\begin{array}{c}\text { Tema Başına Düşen } \\
\text { Etkinlik Ortalaması }\end{array}$ & $\begin{array}{c}\text { Tema Başına Düşen Görsel } \\
\text { Okuryazarlık Kazanımlarına } \\
\text { Yönelik Etkinliklerin } \\
\text { Ortalaması }\end{array}$ \\
\hline Ilkokul Türkçe 1 Ders Kitabı & 4 & 150 & 37.5 & 10.75 \\
\hline $\begin{array}{l}\text { I̧sitme Engelli Öğrenciler için } \\
\text { Hazırlanmış Illkokul 1 Türkçe } \\
\text { Yardımcı Ders Kitabı }\end{array}$ & 4 & 205 & 51.25 & 26.5 \\
\hline
\end{tabular}

Görüldüğü üzere tema sayısı her kitapta da aynıdır fakat tema kapsamındaki etkinlik sayısı "ilkokul Türkçe 1 işitme engelli öğrenciler için hazırlanan yardımcı ders kitabında" daha fazladır.

Illkokul Türkçe 1 ders kitabında görsel okuryazarlık kazanımlarıyla ilgili toplam 43, işitme yetersizliği olan öğrenciler için hazırlanmış ilkokul Türkçe 1 yardımcı ders kitabında ise 106 etkinlik belirlenmiştir. Tüm etkinlikler; dinleme, okuma, konuşma ve yazma olmak üzere 4 ana dil becerisine göre gruplandırılarak belirlenen görsel okuryazarlık kazanımları açısından incelenmiştir. Kitaplardaki çoğu etkinlik birden fazla görsel okuryazarlık becerisiyle ilişkili bulunmuş ve kodlama bu ilişki göz önüne alınarak yapılmıştır.

Ders kitaplarında her bir dil becerisine yönelik görsel okuryazarlığa ilişkin etkinlik sayılarının dağılımı ise Tablo 2'de gösterildiği şekildedir.

Tablo 2.

Ders Kitaplarında Yer Alan Görsel Okuryazarlığa Yönelik Etkinliklerin Beceri Alanlarına Göre Yer Alma Durumu

\begin{tabular}{|c|c|c|}
\hline \multirow[t]{2}{*}{ Dil Beceri Alanı } & $\begin{array}{c}\text { İlkokul } 1 \text { Türkçe Ders } \\
\text { Kitabı }\end{array}$ & $\begin{array}{c}\text { İşitme Engelli Öğrenciler İçin } \\
\text { Hazırlanmış Illkokul Türkçe } 1 \text { Yardımcı } \\
\text { Ders Kitabı }\end{array}$ \\
\hline & Etkinlik Sayısı & Etkinlik Sayısı \\
\hline Dinleme & 4 & 0 \\
\hline Okuma & 15 & 34 \\
\hline Anlama & 41 & 104 \\
\hline Yazma & 24 & 51 \\
\hline
\end{tabular}

Tablo 2'de görüldüğü gibi işitme yetersizliği olan öğrencilerin yardımcı ders kitaplarında; görselleri okuma, anlama ve görsel üzerinde yazmaya yönelik yer alan etkinlik sayısı genel eğitimde kullanılan İlkokul Türkçe 1 kitabından fazla olmasına rağmen işitme yetersizliği olan öğrencilerin kullandığı yardımcı ders kitabında dinleme becerileriyle ilişkili olarak "Görsellerden hareketle 
dinleyeceği/izleyeceği metinle ilgili tahminlerde bulunur." kazanımıyla ilgili hiçbir etkinliğin bulunmadığı saptanmıştır.

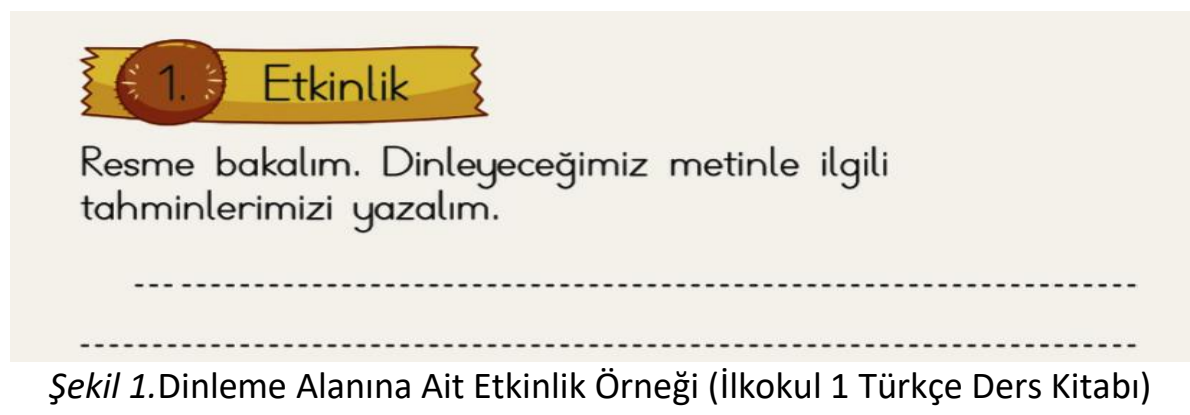

Illkokul 1 Türkçe Ders Kitabında, dinleme alanı ve görsel okuryazarlık beceriyle ilişkili etkinlikler incelendiğinde, "Görselden/görsellerle hareketle dinleyeceği/izleyeceği metin hakkında tahminlerde bulunur." kazanımıyla ilgili etkinliklere yer aldığı görülmektedir. Etkinliklerin hepsinde öğrencilere ilk olarak bir görsel sunulmuş ardından ise dinleyeceği metinle ilgili tahminler yapması istenmiştir. İşitme engelli öğrenciler için hazırlanan Türkçe 1 yardımcı ders kitabında ise dinleme alanına ait bir etkinlik bulunmadığı saptanmıştır.
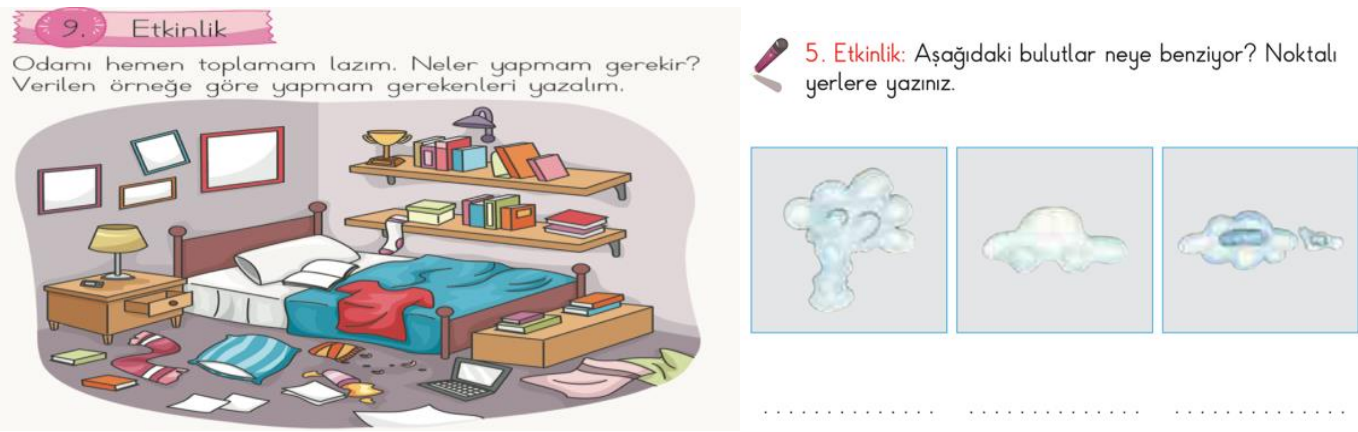

$\begin{array}{lc}\text { Şekil 2.Anlama Alanına Ait Etkinlik Örneği } & \text { Şekil 3. Anlama Alanına Ait Etkinlik Örneği } \\ \text { (illkokul Türkçe } 1 \text { Ders Kitabı) } & \text { (Yardımcı Ders Kitabı) }\end{array}$

Ilkokul Türkçe 1 Ders kitabına bakıldığında, anlama boyutuna ilişkin görsel okuryazarlıkla ilgili etkinliklerin özellikle "Görsellerle ilgili soruları cevaplar." kazanımıyla ilişkili olduğu görülmüştür. Anlama boyutundaki etkinliklerde, görsellere dayalı bulmacalar, resim-kelime etkinlikleri, yönergelere göre boyama, görsellerle ilgili hece çalışmaları, görselleri yorumlama, görsellere uygun ifadeleri seçme, kavram haritası oluşturma, zihin haritası oluşturma, kelimeye uygun yüz ifadelerini bulma, resme göre soruları cevaplama, harita okuma, görsellerden hareketle boşluk doldurma çalışmaları, görsellere dayalı ifade çalışmaları ve şekil ve sembollerin işaretlerinin anlamlarına yönelik sorular bulunmaktadır.

Iş̧itme engelli öğrenciler için hazırlanmış yardımcı Türkçe ders kitabında yer alan anlama boyutuna ilişkin etkinliklere bakıldığında ise; görsellerden hareketle sıralı olayı resmetme, görsellerle $5 \mathrm{n} 1 \mathrm{k}$ çalışmaları, okunulan metinle ilgili boyama çalışmaları, görsellerle ilgili kısa cevaplı sorular (evethayır şeklinde), sıralı hikâye kartlarını olay akışına göre sıralama gibi anlama çalışmalarına yer verildiği görülmektedir. Aynı zamanda kitapta okunulan metin hakkında sorulan çoktan seçmeli soruların bazılarının şıkları görsellerle ifade edilmiş ve öğrencilerden metinle ilişkili görseli bulup işaretlemeleri istenmiştir. 


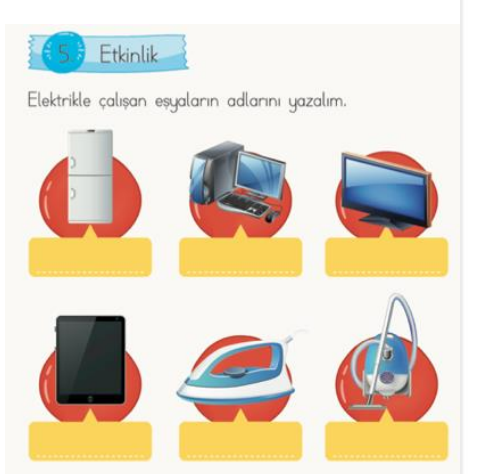

Şekil 4. Okuma Alanına Ait Etkinlik Örneği. (ilkokul Türkçe 1 Ders Kitabı)
1. Etkinlik: Așağıdaki kelimeleri resimlerle eșleștiriniz.

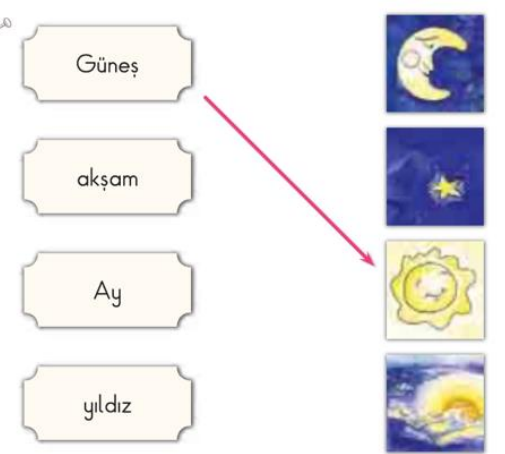

Şekil 5. Anlama Alanına Ait Etkinlik Örneği (Yardımcı Kitap)

Okuma boyutuna ilişkin görsel okuryazarlıkla ilgili ilkokul Türkçe 1 ders kitabındaki etkinliklere bakıldığında, görsellerden faydalanarak okuma çalışmaları ve görsellerden hareketle kelimelerin anlamını bulma çalışmalarının yer aldığı görülmektedir. Aynı zamanda ilgili ders kitabının programda okuma boyutunda yer alan "Farklı yazı karakterleriyle yazıımış yazıları okur." kazanımıyla ilişkili okuma metinlerine sıkça yer verdiği tespit edilmiştir.

İ̧itme engelli öğrenciler için hazırlanmış yardımcı Türkçe ders kitabında yer alan okuma boyutuna ilişkin etkinliklere bakıldığında ise; görsellerden hareketle kelime gruplama çalışmalarına, görsel destekli kelime bulmacalarına, görsel destekli dil bilgisi etkinliklerine, görsellere dayalı boşluk doldurma çalışmalarına, görselleri verilen kelimelerin eksik seslerini tamamlama çalışmalarına yer verildiği görülmüştür. İşitme engelli öğrenciler için hazırlanmış yardımcı Türkçe ders kitabında, illkokul Türkçe 1 kitabının aksine görsellerden faydalanarak serbest okuma etkinliklerine yer verilmemiştir. Bunun yerine şekillere denk gelen harflerle kelime oluşturma çalışmaları yapılmış ve görsel algı desteklenmiştir. Bu kitapta farklı yazı karakterleriyle yazılmış okuma metinlerine ise yer verilmemiştir.

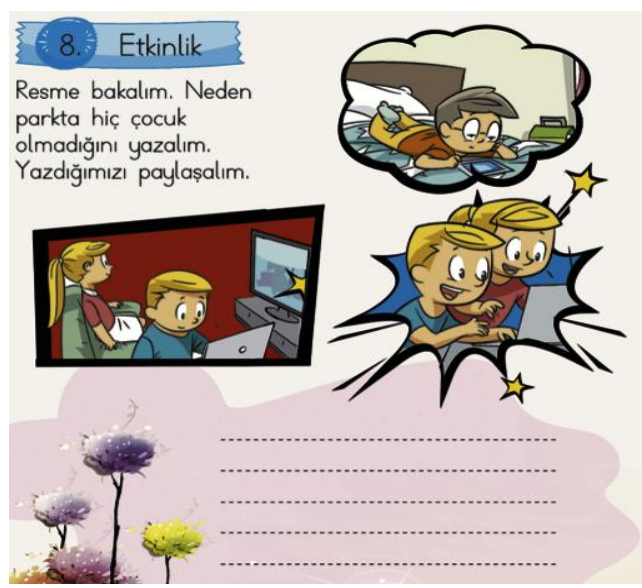

Şekil 6. Yazma Alanına Ait Etkinlik Örneği. (ilkokul Türkçe 1 Ders Kitabı)

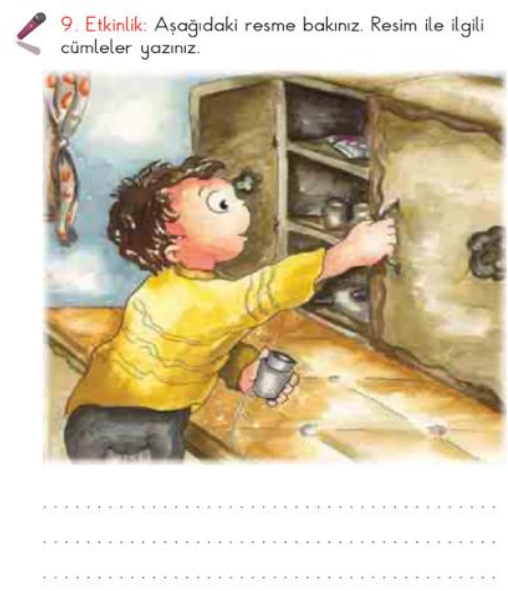

Şekil 7. Yazma Alanına Ait Etkinlik Örneği (Yardımcı Ders Kitabı)

Ilkokul Türkçe 1 Ders kitabında "Görsellerle ilgili kelime ve cümleler yazar." kazanımıyla ilgili nicelik olarak kısmen yeterli etkinlikler bulunsa da, "Yazılarını görsel unsurlarla destekler." kazanımıyla ilgili tek bir etkinliğin yer alması karşımıza önemli bir eksiklik olarak çıkmaktadır. İlkokul Türkçe 1 Ders kitabında yazma boyutuyla ilişkili etkinlikler, görselleri verilen kelimelerle ilgili cümle yazma, görsellerle ilgili kelime yazma, görsellere uygun davranışlarla ilgili cümle yazma gibi çalışmalardan oluşmaktadır. Sadece sayfa 137 'de yer alan etkinlikte öğrencilerden ilgili konu hakkında yazma çalışması yapması ve yazısını görsellerle desteklemesi istenmiştir. Bunun dışında "Yazılarını görsel unsurlarla destekler." kazanımıyla ilgili bir etkinlik kitapta yer almamıştır. 
İşitme engelli öğrenciler için hazırlanmış yardımcı Türkçe ders kitabında yer alan yazma boyutuna ilişkin etkinliklere bakıldığında; görsellerle ilgili cümle yazma, resimli hikâye kartlarındaki görselleri olay sırasına göre anlatan cümleler yazma, görsellere ait cümleleri seçme ve yazma, görsellere uygun kelime yazma, görsellere uygun fiili yazma, görselleri verilen sıralı olayın sonucunu yazma ve resmini çizme, cümlelere uygun resimler çizme, görsellerle ilgili kelimeleri seçip cümle yazma, görsellere uygun zamiri yazma gibi çalışmalara yer verilmiştir. İşitme engelli öğrenciler için hazırlanmış yardımcı Türkçe ders kitabında, illkokul Türkçe 1 kitabına göre dilin yazma boyutuyla ilişkili ve görsel okuryazarlıkla ilgili etkinliklere daha fazla yer vermiştir. Fakat "Yazılarını görsel unsurlarla destekler." kazanımıyla ilgili bu kitapta da sadece iki etkinlik yer almıştır.

Ilkokul Türkçe 1 ders kitabında toplam 4 tema yer almaktadır. Temalara göre görsel okuryazarlığa ilişkin etkinlik sayılarının dağııımı ise Tablo 3 'te gösterilmiştir.

Tablo 3.

Ilkokul Türkçe 1 Ders Kitabında Yer Alan Görsel Okuryazarlığa Yönelik Etkinliklerin Temalara Göre Dağılımı

\begin{tabular}{lccc} 
& & Etkinlik Sayısı & \\
Tema No & Tema Adı & $(\mathrm{f})$ & $\%$ \\
\hline 6 & Çocuk Dünyası & 10 & 23 \\
8 & Doğa ve Evren & 8 & 19 \\
8 & Milli Mücadele ve Atatürk & 10 & 23 \\
9 & Bilim ve Teknoloji & 15 & 35 \\
Toplam & & 43 & 100 \\
\hline
\end{tabular}

Tablo 3'e bakıldığında görsel okuryazarlık ile ilgili toplam 43 etkinlik arasında en fazla görsel okuryazarlık kazanımlarıyla ilişkili etkinliğe sahip olan temanın Bilim ve Teknoloji ( $f=15)$ olduğu görülmektedir. Toplam etkinlik sayısının temalara dağılımı göz önüne alındığında görsel okuryazarlığa yönelik etkinliklerin kısmen yeterli olduğu, fakat yer alan etkinlikleri birçok kazanıma hizmet edecek şekilde uyarlayıp görsel okuryazarlık kazanımlarına yönelik daha fazla etkinliğe yer vermenin mümkün olduğu yorumu yapılabilir.

İşitme engelli öğrenciler için hazırlanmış yardımcı Türkçe ders kitabında da toplamda 4 tema yer almaktadır. Temalara göre görsel okuryazarlığa ilişkin etkinlik sayılarının dağııımı ise Tablo 4 'te gösterilmiştir.

Tablo 4.

İ̧itme Engelli Öğrenciler Için Hazırlanmış ilkokul Türkçe 1 Yardımaı Ders Kitabında Yer Alan Görsel Okuryazarlığa Yönelik Etkinliklerin Temalara Göre Dağılımı

\begin{tabular}{lcc}
\hline Tema Adı & Etkinlik Sayısı (f) & $\%$ \\
\hline Hayal Gücü & 19 & 18 \\
\hline Eğitsel ve Sosyal Etkinlikler & 35 & 33 \\
\hline Değerlerimiz & 28 & 26 \\
\hline Oyun ve Spor & 24 & 23 \\
\hline Toplam & 106 & 100 \\
\hline
\end{tabular}

Tablo 4'e bakıldı̆ıında görsel okuryazarlık ile ilgili toplam 106 etkinlik arasında en fazla görsel okuryazarlık kazanımlarıyla ilişkili etkinliğe sahip olan temanın Eğitsel ve Sosyal Etkinlikler ( $f=35$ ) olduğu görülmektedir.

Görsel okuryazarlığa ilişkin etkinlik sayısı ilkokul Türkçe 1 ders kitabıyla karşılaştırıldığında nicelik olarak işitme engelli öğrenciler için hazırlanmış yardımcı Türkçe ders kitabının daha yeterli olduğu söylenebilir. İşitme yetersizliği olan öğrencilerin daha fazla tekrara ihtiyaç duyması nedeniyle kitabın etkinlik açısından daha fazla olması görsel okuryazarlık becerilerinin kazanılmasında kolaylaştırıcı olacağı düşünülmektedir. 
İşitme Engelliler i̇lkokullarında Kullanılan 1. Sınıf Türkçe Ders Kitaplarındaki Etkinliklerin Görsel Okuryazarlık Açısından İncelenmesi

1. Sınıf Türkçe Öğretim Programında araştırmacılar tarafından belirlenen ve görsel okuryazarlık beceriyle ilişkili olduğu düşünülen yedi kazanım doğrultusunda incelenen etkinlikler dilin "dinleme, anlama, okuma ve yazma" boyutuna göre gruplara ayrılmıştır. Gruplara ayrılan her bir kazanıma ayrı bir kod verilmiştir. Belirlenen kazanımlar ve bu kazanımlarla ilişkili etkinlik sayılarının dağıııı ise Tablo 5 'te gösterilmiştir.

Tablo 5.

Görsel Okuryazarlık Kazanımlarına Yönelik Etkinlik Dağılımı

\begin{tabular}{lcc}
\hline Kazanım & \multicolumn{2}{l}{ Ders Kitabı Adı } \\
\cline { 2 - 3 } & $\begin{array}{l}\text { ilkokul Türkçe 1 } \\
\text { Ders Kitabında } \\
\text { yer alan etkinlik } \\
\text { sayısı }\end{array}$ & $\begin{array}{c}\text { İşitme Engelli Öğrenciler için } \\
\text { Hazırlanmış Ilkokul 1 Türkçe } \\
\text { Yardımcı Ders Kitabında yer } \\
\text { alan etkinlik sayısı }\end{array}$ \\
\hline $\begin{array}{l}\text { Görsellerden hareketle } \\
\text { dinleyeceği/izleyeceği metin hakkında }\end{array}$ & 4 & 0 \\
tahminlerde bulunur. & & 103 \\
\hline Görsellerle ilgili soruları cevaplar. & 37 & 0 \\
\hline $\begin{array}{l}\text { Görsellerden hareketle okuyacağı metnin } \\
\text { içeriğini tahmin eder. }\end{array}$ & 2 & 1 \\
\hline Şekil, sembol ve işaretlerin anlamını kavrar. & 2 & 34 \\
\hline Görsellerden hareketle kelimeleri ve & 15 & 50 \\
anlamlarını tahmin eder. & 23 & 2 \\
\hline Görsellerle ilgili kelime ve cümleler yazar. & 1 & \\
\hline Yazılarını görsel unsurlarla destekler. & & \\
\hline
\end{tabular}

Tablo 5'e bakıldığında hem işitme yetersizliği olan öğrenciler için hazırlanmış yardımcı ders kitabı ve hem de ilkokul Türkçe 1 ders kitabında en çok anlama boyutuna ilişkin "Görsellerle ilgili sorulara cevap verir." kazanımına yönelik etkinliklerin olduğu görülmektedir. Illkokul Türkçe 1 ders kitabında en az yer verilen kazanım ise "Yazılarını görsel unsurlarla destekler." kazanımı olmuştur. İşitme engelli öğrenciler için hazırlanmış yardımcı ders kitabında ise dinleme boyutuna ilişkin "Görsellerden hareketle dinleyeceği/izleyeceği metin hakkında tahminlerde bulunur." kazanımına hiç yer verilmediği görülmektedir. Türkçe Öğretim Programda dilin dinleme boyutuna ilişkin olarak görsel okuryazarlık becerileri ile ilişkili kazanımlar yer alırken işitme engelli öğrenciler için hazırlanmış ilkokul Türkçe 1 yardımcı ders kitabında yer alan etkinliklerde rastlanmaması önemli bir eksiklik olarak karşımıza çıkmaktadır. Bunun yanı sıra söz konusu kitapta dinleme becerilerine yönelik diğer kazanımlarla ilişkili etkinlik örnekleri de bulunmamaktadır.

\section{Tartışma ve Sonuç}

Değişen dünyayla beraber görselliğin ve görsel okuryazarlığın her geçen gün öneminin artığı aşikardır. Bu sebeple görsel okuryazarlık becerilerinin öğretimine erken yaşta başlamak günümüz dünyası için bir gereklilik haline gelmiştir. Eğitim kurumlarında görsel okuryazarlık becerilerinin planlı ve düzenli bir şekilde diğer becerilerle birlikte kazandırılması hedeflenmektedir. Türkçe dersi öğretim programlarında da kendine yer bulan görsel okuryazarlık becerileri okuryazar olma yolunda ilk adımlarını atmış ilkokul birinci sınıf öğrencilerine de çeşitli etkinlik ve alıştırmalarla kazandırılmaktadır. Görsel okuryazarlık becerilerinin kazandırılabilmesi için etkinlikler ve buna bağı olarak da etkinliklerin yer aldığı ders ve çalışma kitaplarının niteliği önem arz etmektedir. Bu çalışmada ders kitaplarında görsel okuryazarlığa ilişkin etkinliklerin var olma durumu incelenmiş ve gelişimsel geriliği olan işitme yetersizliği olan öğrenciler için özel olarak hazırlanan yardımcı kitabın da görsel okuryazarlık becerilerini etkinliklerle destekleme konusunda ne durumda olduğu belirlenmeye çalışılmıştır. 
Ilkokul Türkçe ders kitabı ve işitme engelli öğrenciler için hazırlanan Türkçe yardımcı ders kitabında toplam 355 etkinlik incelenmiştir. İlkokul Türkçe 1 kitabında görsel okuryazarlık becerileriyle ilişkili 43 etkinlik, işitme engelli öğrenciler için hazırlanan Türkçe yardımcı ders kitabında ise 106 etkinlik tespit edilmiştir. Bu açıdan işitme yetersizliği olan öğrenciler için hazırlanan yardımcı ders kitabının görsel okuryazarlık beceriyle ilişkili etkinlikler açından daha zengin olduğu söylenebilir. Fakat işitme engelli öğrenciler için hazırlanan Türkçe 1 yardımcı ders kitabında dinleme boyutuna ait kazanımlara ilişkin etkinlikler bulunmadığı da tespit edilmiştir. Oysaki gelişen duyma teknolojileriyle bireyin işitmesine imkan tanınmakta ve işitmeyle ilişkili beceriler işitme yetersizliği olan bireyler tarafından edinilebilir hale gelmektedir. Gelişen teknoloji ve cihazlarla sesleri algılayabilen birey ise ses ile ilgili yaşantılara işitme duyusunu kullanarak bilinçli katılım gösterebilmektedir (Cole \& Flexer, 2007). Bu sebeple işitsel bir eğitimin parçası olan dinleme becerilerinin eğitimi işitme yetersizliği olan bireyler için oldukça önemlidir. Ulusal Yenidoğan İşitme Tarama Programı ile işitme yetersizliği olan birçok bebek en erken şekilde tanılanmakta ve uygun cihazlandırma ile bebeğin işitmesi sağlanmaktadır. Tuckner (1998) ise, işitme yetersizliği olan bireyin erken tanı, uygun cihazlandırma ve doğru işitme ve dinleme eğitimi ile işitsel algılama, ayırt etme, tanıma ve anlama becerilerinin gelişeceğini ve ana dil gelişiminin olumlu etkileneceğini belirtmiştir (Akt. Girgin, 2006). Bu sebeple ki dinleme becerilerinin ediniminin işitme yetersizliği olan öğrenciler içinde çok önemli olduğu ve doğru eğitim ile kazandırılıp desteklenmesi gerektiği açıktır. Fakat işitme engelli öğrenciler için hazırlanan Türkçe 1 yardımcı ders kitabında dinleme boyutuna ait kazanımlara ilişkin etkinliklerin bulunmaması onların bu beceri alanının gelişimine gereken önemin verilmediğinin de bir ispatıdır.

Incelenen her iki kitapta da görsellere yönelik tahminler, görsellerle ilgili sorular, metnin içeriğini tahmin etmeye yönelik görseller, şekil ve sembollerin anlamına ilişkin etkinlikler, görseller ilgili yazma çalışmaları gibi farklı uygulamalara da yer verilmiş olsa da, incelenen kitaplarda ek soru oluşturma ve bütünleyici çalışmalarda eksiklikler olduğu görülmüştür. Görsel okuryazarlık kazanımlarına ilişkin yer alan soru ve uygulamaların her iki kitapta da dilin anlam bilgisi yönüne odaklandığı tespit edilmiştir. Buna karşın özellikle işitme yetersizliği olan öğrenciler için hazırlanmış ilkokul Türkçe 1 yardımcı ders kitabında dinleme becerisine yönelik soru ve etkinliklerin bulunmaması önemli bir eksiklik olarak ortaya çıkmıştır. Oysaki, işitme yetersizliği olan öğrencilerin dinleme becerilerini geliştirmeye yönelik etkinliklere yer vermek onların gelişimini desteklemek adına çok önemlidir. Özellikle, görseller üzerinden konuşmak, tahminler yapmak gibi etkinlikler onların dinleme becerilerini geliştirmesinde kolaylaştırıı rol oynamaktadır. Bu sebeple, dinleme becerileriyle ilişkili olarak görsel okuryazarlık becerilerine yönelik etkinlikler hazırlamak onların eğitim sürecini desteklemektedir.

Tema başına düşen görsel okuryazarlık kazanımlara yönelik etkinlikler açısından, işitme yetersizliği olan öğrenciler için hazırlanmış yardımcı ders kitabında görsel okuryazarlığa yönelik daha fazla etkinliğin yer aldığı görülmektedir. Genel olarak söylemek gerekirse, işitme yetersizliği olan öğrenciler için hazırlanmış yardımcı ders kitabında etkinlik sayısının daha fazla olması olumlu bir durumdur. Çünkü işitme yetersizliği olan çocuklar eğitim süreçlerinde normal gelişen akranlarına kıyasla bilginin daha çok tekrarlanmasına ihtiyaç duymaktadırlar (Luckner, vd., 2005/2006). Burada dikkat edilmesi gereken en önemli nokta, bu etkinlikleri yürütürken işitme yetersizliği olan öğrencilerin farklılaşan özelliklerinin öğretmen tarafından fark edilip dikkate alınması ve bu etkinlikleri her çocuk için özel olarak hazırlanan bireyselleştirilmiş eğitim programlarında çocuğun ihtiyaçları doğrultusunda yansitabilmesidir.

Alanyazına bakıldığında, Akçay ve Okur Akçay (2017) yaptığı çalışmada, resimli hikâye kartlarının ifade etme becerilerine olan olumlu etkisini ortaya çıkarmışlardır. Alıcı ve ifade edici sözel dil gelişiminde yaşıtlarının gerisinde performans sergileyen işitme yetersizliği olan çocuklar göz önüne alındığında, onlara sunulacak etkinliklerin hikâye kartlarıyla ifade etme, görseller üzerine konuşma, görseller üzerinden tahmin yapma, görsellerle ilgili dinleme çalışmaları yapma gibi daha yoğun görselli ve görsel okuryazarlık becerilerini geliştirici uygulamalardan oluşması önem arz etmektedir. Bu çalışma da ise, "Görsellerden hareketle dinleyeceği/izleyeceği metin hakkında tahminler bulunur" kazanımına ilişkin etkinliklere işitme engelli öğrenciler için hazırlanmış yardımcı Türkçe ders kitabında hiç yer verilmediği tespit edilmiştir. Bu durumun, işitme yetersizliği olan öğrencilerin alıcı ve ifade edici dil 
gelişimlerin desteklenmesi için gerekli olan alıştırma ve etkinliklerin niteliğini olumsuz etkileyeceği düşünülmektedir. Çünkü dil tüm alt boyutlarıyla beraber bir bütündür ve öğretiminin de bir bütünsellik içinde olması gereklidir. Yine ayrı bir çalışmada ise, Örs ve Baş (2017) öğrenciler için hazırlanan görsel sunu ve görsel okuma etkinliklerinin öğrencilerin öğrenmelerine olumlu etki ettiğini ve öğrendiklerini zihinlerinde yapılandırmalarına olumlu etki ettiğini tespit etmiştir. Yaptıkları çalışmada, hazırladıkları etkinliğin "Görsellerden hareketle cümleler ve metinler yazar." kazanımını öğrencilerde geliştirmeye yönelik destekleyici olduğunu belirtmişlerdir. Bu çalışmada da, benzer şekilde "Görsellerle ilgili kelime ve cümleler yazar" kazanımını geliştirmeye yönelik etkinlikler ders kitaplarında incelenmiştir. Fakat ders kitaplarının her ikisinde de öğrencilerin ayrıntılara dikkat ederek görselleri yorumladığı etkinliklere çok daha az yer verildiği tespit edilmiştir. Oysaki görsel okuryazarlık, görsellerdeki ayrıntılara dikkat ederek görsel mesajları doğru yorumlamak ve bu mesajları sözel ya da yazılı olarak ifade edebilmeyi içermektedir. Bu kazanıma yönelik çeşitli ve farklı seviyedeki etkinliklere bu kazanımın edinilebilmesi için daha sık yer verilmesi gerektiği düşünülmektedir. Çünkü özel eğitim gereksinimi olan grupta bulunan işitme yetersizliğine sahip öğrenciler daha yoğun tekrara ihtiyaç duymaktadır. Örs ve Baş'ın (2017) yine aynı çalışmasında, görsel materyallerle ders sunumu sonrası öğrencilerden çalışma kağıtlarını doldurmaları istenmiş ve öğrencilerin normal ders süreçlerinden daha rahat yazı yazdıkları görülmüştür. Bu bulguyla ders kitaplarında yer alan etkinliklere ek olarak bütünleyici etkinliklerin kullanımının önemi bir kez daha ortaya çıkmıştır. Özellikle dil ve dile bağlı gelişim alanları da problemler yaşayan işitme yetersizliği olan öğrenciler için okuma yazma öğrenme ortamlarını görsel materyallerle desteklemek onların okuma yazmaya karşı motivasyonunu olumlu etkileyecektir. Bireylerin sahip oldukları potansiyeli en iyi düzeyde ortaya koyabilmesini amaçlayan özel eğitimde, işitme yetersizliği olan bireylerin güçlü yanlarının desteklenerek onlara en uygun eğitim ve sağaltımın sağlanması da oldukça önemlidir. Aynı şekilde, işitme yetersizliği olan öğrenciler gibi farklı bireysel özelliğe sahip öğrenciler için ise bütünleyici etkinliklere ek olarak etkinliklerin uyarlanabilir olmasının bir gereklilik olduğu düşünülmektedir. Bu araştırmada incelen her iki kitap için ise uyarlamanın uygulayıcı tarafından yapılabilir nitelikte olduğu saptanmıștır.

Temizkan ve Ünlüoğlu (2017) yaptığı çalışmada ise, görsel destekli yazma etkinliklerinin yazııı anlatım becerisinin gelişmesinde olumlu bir etkiye sahip olduğunu belirtmişlerdir. Bu araştırmada ise, işitme engelli öğrenciler için hazırlanan Türkçe 1 yardımcı ders kitabı ve illkokul Türkçe 1 ders kitabında "Görsellerle ilgili kelime ve cümleler yazar." kazanımına ilişkin sayıca kısmen yeterli etkinliğin yer aldığı görülse de "Yazılarını görsel unsurlarla destekler." kazanımına yönelik çok az sayıda etkinlik tespit edilmiştir. Oysaki görsel destekli yazma etkinliklerinin yazılı anlatım becerilerinin dil ve anlatım yönünü destekleyen araştırma bulguları mevcuttur (Temizkan \& Ünlüoğlu, 2017). Yazılı anlatım becerilerinde işiten akranlarına kıyasla problemler yaşayan işitme yetersizliği olan öğrencilerin (Erdiken, 2010) yazılı anlatım becerilerini görsel unsurlarla desteklemek ve bu doğrultuda kullanılan ders kitaplarında görsel destekli yazma etkinliklerine yer vermek önemlidir. Öztürk ve Kavas (2019), 2018 Türkçe Dersi Öğretim Programını görsel okuma ve görsel sunu becerileri açısından incelediği araştırmasında, programın dinleme alt boyutuna ilişkin görsel okuma ve sunu kazanımlarıyla öğrencilerin iyi bir medya okuru olabilmelerinin hedeflendiğini ortaya koymaktadır. Fakat araştırmada ilkokul Türkçe 1 ders kitabında "Görselden/görsellerden hareketle dinleyeceği/izleyeceği metin hakkında tahminde bulunur." kazanımına ait sadece 4 etkinlik, işitme engelli öğrenciler için hazırlanan ilkokul Türkçe 1 yardımcı ders kitabında ise bu kazanıma yönelik hiç etkinlik bulunmaması önemli bir eksiklik olarak karşımıza çıkmaktadır. Bu bağlamda, kazanımın hedefine ulaşabilmesi için sadece ders kitaplarının eğitim materyalli olarak kullanılması son derece yetersiz kalacaktır. Fakat ilgili alan yazın öğretmenlerin sıklıkla kullandığı materyalin ders kitapları olduğunu göstermektedir (Ceyhan \& Yiğit, 2005). Ders kitaplarındaki etkinliklerin eğitim programlarında yer alan kazanımlarla uyuşması hedef davranış örüntülerini öğrenciye kazandırabilmesi için çok önemlidir. Araştırmada incelenen ders kitaplarında ayrıca, sadece görselleri kullanarak mesaj iletmelerini sağlayan etkinliklere de rastlanmamaktadır. Öztürk ve Kavas (2019) yaptığı çalışmada görselleri kullanarak mesaj oluşturmaya dair kazanımların ayrıca Türkçe dersi öğretim programında da yer almadığını belirtmiştir. Oysaki görsel bir dil kullanan işitme yetersizliği olan öğrenciler için görselleri kullanarak kendini ifade etmesine yönelik etkinliklerin onların iletişim becerilerini güçlendireceği düşünülmektedir. İşitme yetersizliği olma durumundan 
bağımsız işiten akranlarıyla aynı görsel kitle iletişim araçlarını kullanmayı ve görselleri anlamlandırabilmeyi işitme yetersizliği olan öğrencilere kazandırabilmek onların toplumla bütünleşmesi için de ayrıca önemlidir.

Bu doğrultuda söylenebilir ki, ders kitapları özellikle etkinliklerinde ek soru oluşturma vb. yöntemlerle daha fazla kazanıma hizmet edecek şekilde uyarlanmalıdır. Etkinliklerde öğrenme alanlarının tümüne yönelik eşit soru ve etkinliklere yer verilmelidir. Öğrencilerin bulundukları sınıf düzeyinin öğretim programında yer alan kazanımları edinmeleri ve ihtiyaç duydukları alıştırma ve tekrar yaşantılarının kazandırılması için etkinliklerin hedef kazanımlarla örtüşmesi gerekir. Bu yüzden, kitaplarda kullanılan etkinlikler ile programda yer alan kazanımların örtüşmesine daha çok özen gösterilmelidir. İşitme yetersizliği olan öğrencilerin işiten akranlarıyla aynı müfredat ile eğitim öğretime devam ettikleri düşünüldüğünde illkokul Türkçe 1 kitabında görsel okuryazarlık kazanımlarına yönelik etkinliklerinin sayısı artırılabilir. İşitme yetersizliği olan öğrencilerin dinleme becerilerini geliştirmeye yönelik etkinliklere işitme yetersizliği olan öğrenciler için hazırlanmış ilkokul 1 Türkçe yardımcı ders kitabında öğrencilerin işitme kayıpları da göz önüne alınarak yer verilebilir.

Ayrıca, Türkçe ders ve yardımcı ders kitaplarında yer alan etkinliklerin ve programda yer alan kazanımların arasında bir bütünlük ve bağ beklenmektedir. Yer alan çalışmaların farklı bireysel özelliğe sahip öğrencilere sunulacağı göz önüne alındığında etkinliklerin uyarlanabilir olması gerekmektedir. Fakat, ilkokul Türkçe 1 ders kitabı ve İşitme engelli öğrenciler için hazırlanmış yardımcı ders kitabında düzey açısından önemli farklılıklar bulunmaktadır. Ayrı bir müfredata sahip olmayan işitme yetersizliği olan öğrencilerin eğitsel performansları göz önüne alındığında genel eğitim sınıflarında kullanılan ilkokul Türkçe 1 ders kitabının onlar için fazlasıyla ağır olduğu söylenebilir. Çünkü bilinmektedir ki işitme yetersizliği olan bireyler okuma bilgisini edinmede yaşıtlarıyla karşılaştırıldığında daha fazla problem yaşarlar (Smith, 2004). Bununla birlikte işitme yetersizliği olan öğrencilerin yazma problemleri de yaşadığı ve yazma performanslarının işiten akranlarından daha geri olduğu bilinmektedir (Cepdibi, 2020; Efe \& Karasu, 2017; Karasu \& Girgin, 2007; Sümer \& Turna, 2018). íki ders kitabının bilgi ve zorluk düzeyinin birbirinden farklı olması nedeniyle bu iki kitabın birbirini tamamlar nitelikte olduğunu söylemek güçtür. Fakat işitme yetersizliği olan öğrencilerin ayrı bir müfredata sahip olmamaları, öğretim programları üzerinde işiten akranlarıyla aynı becerileri kazanmasının beklenmesi onların aynı ders materyallerini kullanmalarını gerektirmektedir. Fakat işitme yetersizliği olan öğrencilerin özellikle dil ve dilin alt boyutlarına ilişkin performansları göz önüne alındığında onlara yönelik bir müfredat ve ders materyali oluşturulmasının gerekliliği daha net anlaşımaktadır.

Genel olarak işitme yetersizliği olan öğrenciler için en büyük eksikliğin, onların gelişimlerine uygun düzeylendirilmeyen kazanımlara sahip eğitim programlarına devam etmesidir. Bu sebeple, genel eğitim programlarındaki hedef kazanımlar işitme yetersizliği olan öğrencilerin performans ve ihtiyaç düzeyine uygun olmamaktadır. Onlar daha yoğun, daha kapsamlı ve gelişimsel özellikleri dikkate alınarak hazırlanmış programlara ihtiyaç duymaktadır. Bu çalışmanın bulgularından hareketle ise şu öneriler verilebilir:

- Türkçe ders ve etkinlik kitaplarında dil ve dile ait tüm boyutlar bütüncül bir şekilde ele alınmalı ve görsel okuryazarlık becerileri dile ait tüm boyutlarda desteklenmelidir.

- Ders kitapları hazırlanırken çocuğa görelik ilkesi göz önünde bulundurulmalı ve etkinlikler her çocuğa uyarlanabilir olmalıdır.

- Görsel okuryazarlığa ilişkin becerilerin genellenmesi ve kalıcılığı için etkinlik önerileri ders kitaplarında yer almalıdır.

\section{Kaynaklar}

Akçay, A. ve Akçay, N. O. (2017). Hikâye kartlarının çocukların görsel ifade becerileri üzerindeki etkisi. Ana Dili Eğitimi Dergisi, 5 (3), 417-432.

Akpınar, B. (2009). İlköğretim 1-5. sınıflar Türkçe öğretim programları görsel okuma ve sunu öğrenme alanının değerlendirilmesi. Eğitim ve Bilim, 34 (154), 37-47.

Alpan Bangir, G. (2008). Görsel okuryazarlık ve öğretim teknolojisi. Yüzüncü Yıl Üniversitesi Eğitim Fakültesi Dergisi, 11, 74-102. 
İşitme Engelliler i̇lkokullarında Kullanılan 1. Sınıf Türkçe Ders Kitaplarındaki Etkinliklerin Görsel Okuryazarlık Açısından İncelenmesi

Artam, B. ve Baştuğ, Ö. (2017). Illkokul Türkçe 1 işitme engelli öğrenciler için hazırlanan yardımcı ders kitabı. Ankara: Milli Eğitim Bakanlı̆̆ı.

Cepdibi, S. (2020). Iş̧itme yetersizliği olan öğrencilerin yazılı dil becerilerinin karşılaştırmalı olarak incelenmesi (Yayımlanmamış yüksek lisans tezi). Ankara Üniversitesi Eğitim Bilimleri Enstitüsü, Ankara.

Ceyhan, E. ve Yiğit, B. (2005). Konu alanı ders kitabı incelemesi (3. Baskı). Ankara: Anı Yayıncılık.

Civelek, D., Yılmaz Gündüz, D. ve Karafilik, F. (2019). ilkokul Türkçe 1 ders kitabı. Ankara: Milli Eğitim Bakanlığı.

Cole, E., \& Flexer, C. (2007). Children with hearing loss: Developing listening and talking, birth to six.

San Diego: Plural Publishing.

Çevik, A. ve Güneş, F. (2017). Türkçe ders kitaplarındaki etkinliklerin incelenmesi. Ana Dili Eğitimi Dergisi, 5 (2), 272-286.

Demirel, Ö. ve Kıroğlu, K. (2019). Ders kitabı incelemesi (3. Baskı). Ankara: Pegem Yayıncılık.

Efe, A \& Karasu, P . (2017). Kaynaştırma Eğitimine Devam Eden İşitme Engelli Öğrencilerin Yazdıkları Öykülerin İncelenmesi . Ankara Üniversitesi Eğitim Bilimleri Fakültesi Özel Eğitim Dergisi, 18(3), 329-354 .

Girgin, Ü. (1997). Eskişehir ili ilkokulları 4 ve 5. sınıf işitme engelli öğrencilerinin okumayı öğrenme durumlarının çözümleme ve anlama düzeylerine göre değerlendirilmesi. Eskişehir: Anadolu Üniversitesi Eğitim Fakültesi Yayınları.

Girgin, M. C. (2006). İşitme engelli çocukların konuşma eğitiminde dinleme becerilerinin önemi. Ankara Üniversitesi Eğitim Bilimleri Fakültesi Özel Eğitim Dergisi, 7(1), 15-28.

Güvendi Kaptan, S. ve Kaptan, A. Y. (2004, Temmuz). Ders kitaplarındaki tasarım sorunları ve öğrencilerin öğrenme düzeyine etkisi. XIII. Ulusal Eğitim Bilimleri Kurultayı'nda sunulmuş sözlü bildiri. Malatya: İnönü Üniversitesi Eğitim Fakültesi.

Karal, Y , Şılbır, L , Bahçekapılı, E. ve Atasoy, M . (2015). İşitme engelli bireyler için grafik sembollerle oluşturulmuş öğrenme materyalleri. Journal of Instructional Technologies and Teacher Education, 3 (3).

Karasu, P. \& Girgin, Ü. (2007). Kaynaştırmadaki işitme engelli çocukların yazılı anlatım becerilerinin değerlendirilmesi. Anadolu Üniversitesi Sosyal Bilimler Dergisi, 7(1), 467-488.

Luckner, J. L, Sebald, A. M., Cooney, J. Young III, J., \& Muir, S. G. (2005/2006). An examination of the evidence based literacy research in deaf education. American Annals of Deaf, 150 (5), 443-455.

Marschark, M., Paivio, A., Spencer, L. J., Durkin, A., Borgna, G., Convertino, C., \& ark. (2017). Don't assume deaf students are visual learners. Journal of developmental and physical disabilities, 29 (1), 153-171.

Maxwell, J. A. (2018). Nitel araştırma tasarımı. Etkileşimli bir yaklaşım. (Çev. Mustafa Çevikbaş (Ed.)). Ankara: Nobel Yayıncılık.

Milli Eğitim Bakanlığı. (2008). ilköğretim okulu ders kitaplarının değerlendirilmesi. Ankara: Milli Eğitim Bakanlığı, Eğitimi Araştırma ve Geliştirme Dairesi Başkanlığı.

Milli Eğitim Bakanlığı Ders Kitapları ve Eğitim Araçları Yönetmeliği. (2012, 12 Eylül). Resmi Gazete (28409). Erişim Adresi: http://mevzuat.meb.gov.tr/dosyalar/1605.pdf.

Milli Eğitim Bakanlığı (2018). Türkçe dersi öğretim programı (ilkokul ve ortaokul 1., 2., 3., 4., 5., 6., 7., ve 8. sınıflar). Ankara: Milli Eğitim Bakanlığı.

Nikolaraizi, M., Vekiri, I., \& Easterbrooks, S. (2013). Investigating deaf students' use of visual multimedia resources in reading comprehension. American Annals of the Deaf, 157(5), 458473.

Örs, E. ve Baş, B. (2018). İkinci sınıf öğrencilerinin görsel okuryazarlığı üzerine bir araştırma. Ana Dili Eğitimi Dergisi, 6 (1), 95-113.

Özden, Y. (2005). Eğitimde yeni değerler (6. Baskı). Ankara: Pegem Yayıncılık.

Özmantar, M. ve Bingölbali, E. (2009). Sınıf öğretmenleri ve matematiksel zorlukları. Gaziantep Üniversitesi Sosyal Bilimler Dergisi , 8 (2) , 401-427.

Öztürk, I. Y. ve Kavas, M. (2019). Görsel okuma ve görsel sunu becerileri bağlamında 2018 Türkçe dersi öğretim programı kazanımlarının incelenmesi. Eğitim ve Yeni Yaklaşımlar Dergisi, 1, 23-39. 
Smith, F. (2004). Understanding reading. USA: Lawrence Erlbaum Associates Publishers.

Sümer, H. M., \& Turna, C. (2018). İşiten ve işitme yetersizliği olan öğrencilerin özetleme becerileri açısından incelenmesi. Ankara Üniversitesi Eğitim Bilimleri Fakültesi Özel Eğitim Dergisi, 19(3), 531-551.

Temizkan, M. ve Ünlüoğlu, C. (2017). Görsel destekli yazma etkinliklerinin öğrencilerin yazma başarılarına ve yazmaya yönelik görüşlerine etkisi. Dicle Üniversitesi Ziya Gökalp Eğitim Fakültesi Dergisi, 30, 437-448.

\section{Extended Abstract}

\section{Introduction}

Literacy of today's world is gaining much more visuality. Visual literacy with its increasing importance is one of the most important among the basic skills in general education (Akpınar, 2009). "Visual literacy skills" took part in the Turkish curriculum (MoNE, 2018) and, the curriculum included the objectives which is serving to development of visual literacy. Visual literacy is an important power, especially for teachers, that can be used to increase the quality of the learning process. Also, it is important to gain and support visual literacy skills for students with special needs and students who need information presented differently.

Based on this idea that deaf children in the group that requires an individualized education are visual learners throughout their academic life (Marschark, Pavio, Spencer, Durkin, Borgna, Convertino \& Machmer, 2016), in this study, the books used by the deaf students in Turkish lessons were examined by considering the qualitative and quantitative characteristics of the activities for visual literacy. There is no study investigating the visual literacy skills of deaf students who use sign language, a visual language, in national literature. For this reason, it was thought that this research will fill the gap in the literature.

\section{Method}

Document analysis methodology was used for this research. The aim of the research is to examine the activities' "the Turkish 1 elementary textbook (Civelek, Gündüz \& Karafilik, 2019)" and "Turkish 1 supplementary textbook for the deaf (Artam \& Baştuğ, 2017)" in terms of whether it includes the objectives that are thought to serve the development of visual literacy skills in "Turkish curriculum(MEB, 2018)". For this reason, the approach that was used is qualitative in this research. Before the data analysis, the objectives in the Turkish curriculum was examined in detail and, the activities in the textbook were screening through the objectives in the curriculum. With Maxwell's definition, based on the similarity analytical strategy was used in this research. The circumstance of the activities in the textbook, whether is included visual literacy skills, which are categorized according to 7 objectives that are thought to be related to visual literacy in the curriculum was determined by these categories and, the activities were classified. In the classifying process, a categorical encoding matrix was used.

\section{Result and Discussion}

43 activities relevant to visual literacy objectives in the Turkish 1 elementary textbook and, 106 activities relevant to visual literacy objectives in the Turkish 1 elementary supplementary textbook for the deaf was determined. In the "Turkish 1 elementary supplementary textbook for the deaf", it has been determined that there is no activity related to the objective "S/he makes predictions about the text $\mathrm{s} /$ he will listen/watch based on the visual." If in "The Turkish 1 elementary textbook", there are sufficient activities quantitatively related to the objective "S/he writes words and sentences about image." But, there is only one activity related to the objective "S/he supports his/her writing by using visuals". This circumstance has emerged as an important deficiency.

Whereas, it is very important that including activities aimed at improving the listening skills of students who are deaf, because of supporting their development. Especially, activities such as conversation about visuals, guessing games, etc. play a key role for development of listening skills. For 
İşitme Engelliler i̇lkokullarında Kullanılan 1. Sınıf Türkçe Ders Kitaplarındaki Etkinliklerin Görsel Okuryazarlık Açısından İncelenmesi

this reason, it is thought that, activities about visual literacy relevant to listening skills would support their education and development process who are deaf. 